\title{
IMMUNOCHEMICAL STUDIES ON BLOOD GROUPS
}

\author{
ViII. The Methylpentose Contents of Hog and Human Blood Group A \\ and O Substances and Their Relationship to Cross-Reactivity with \\ TyPe XIV ANTIPNEumococcus Horse SERUM* \\ By HaRold Baer, Ph.D., ZaCharias Dische, M.D., and ELVIN A. \\ KABAT, PH.D. \\ (From the Departments of Neurology, Bacteriology, and Biochemistry, College of \\ Physicians and Surgeons, Columbia University, and the Neurological Institute \\ of New York)
}

(Received for publication, March 15, 1948)

The presence of $l$-fucose in purified blood group $A$ and $O$ substances from hog gastric mucosa has been established in three laboratories (1-3). In the preceding paper (4) it was shown that heating at $\mathrm{pH}$ 1.5-1.8 liberated most of the fucose from the polysaccharide. Since the heating at $\mathrm{pH}$ 1.5-1.8 also increased the ability of the blood group substances to cross-react with Type XIV antipneumococcus serum, it was suggested that this increased cross-reactivity resulted from the removal of fucose residues projecting as end groups from the main polysaccharide chain. It had previously been demonstrated (5) that preparations of hog blood group A substances from individual hog stomach linings varied in their capacity to precipitate Type XIV antibody although they were identical in blood group A activity and it was considered of interest to investigate the fucose content of these substances to determine whether the fucose was responsible for this variation. For this purpose the newly developed specific color reaction for methylpentoses (6) was employed and the methylpentose contents of the various hog and human blood group substances determined. These values are assumed to represent fucose which is the only methylpentose known to be present in the blood group substances (1-4). Considerable variation in the methylpentose contents of the individual samples of blood group substances was found. Among the hog blood group $A$ and $O$ substances the methylpentose content varied inversely with the degree of cross-reactivity with Type XIV antipneumococcal serum.

\section{EXPERIMENTAI}

The individual preparations of hog and human blood group substances are identical with those described in the previous studies $(2,7,8)$.

* The work described in this paper was carried out under a research grant from the Division of Research Grants and Fellowships of the National Institute of Health, United States Public Health Service, and in part under the William J. Matheson Commission and the Cancer Research Division of the Donner Foundation, Inc. 
Methylpentose was determined (6) by slowly adding to $1 \mathrm{ml}$. of an ice cold solution of the blood group substance containing between 3 and $10 \mu \mathrm{g}$. of methylpentose, $4.5 \mathrm{ml}$. of sulfuric acid solution ( 6 parts of acid to 1 part of water by volume). The addition of the acid was made slowly and with constant shaking in an ice bath to prevent a rise in temperature. The tubes were transferred to a water bath at room temperature for a few minutes, then to a vigorously boiling water bath, which should not cease boiling when the tubes are inserted. After being heated for exactly 3 minutes, the tubes were placed in a water bath at room temperature. $0.1 \mathrm{ml}$. of a 3 per cent solution of cysteine hydrochloride (prepared weekly and stored under refrigera tion) was added and the tubes were thoroughly mixed. After 2 hours the absorption was measured in a Beckman spectrophotometer at 3960 and $4300 \mathrm{~A}$, the difference being directly proportional to the methylpentose content of the solutions (6).

TABLE I

Fucose Content of Hog Blood Group $A$ and $O$ Substances

\begin{tabular}{|c|c|c|c|c|c|}
\hline $\begin{array}{l}\text { Blood group } \\
\text { A substance }\end{array}$ & Fucose & $\begin{array}{c}\text { Cross- } \\
\text { reactivity* }\end{array}$ & $\begin{array}{l}\text { Blood group } \\
\text { O substance }\end{array}$ & Fucose & $\begin{array}{l}\text { Cross- } \\
\text { reactivity* }\end{array}$ \\
\hline & per cent & $\mu g . N$ & & per cent & $\mu g \cdot N$ \\
\hline Hog 3 & $6.8,6.6$ & 72 & $\operatorname{Hog} 6$ & 6.5 & 65 \\
\hline 5 & $8.2,8.3$ & & 13 & 6.8 & 64 \\
\hline 8 & 7.3 & 72 & 19 & 11.5 & 23 \\
\hline 10 & 8.9 & 19 & 25 & $11.2,14.2$ & 23 \\
\hline 14 & $7.7,7.8$ & & 27 & $7.3,7.4,7.8$ & 80 \\
\hline 15 & $9.9,9.2$ & 35 & 29 & $9.5,8.8,8.9,8.3,8.1$ & 63 \\
\hline 16 & 9.6 & 39 & 32 & 5.7 & 118 \\
\hline
\end{tabular}

${ }^{*} \mu \mathrm{g}$. of $\mathrm{N}$ precipitated by $500 \mu \mathrm{g}$. of blood group substance from $0.5 \mathrm{ml}$. of Type XIV antipneumococcus horse serum H635 (cf. 5).

All analyses for fucose carried out on samples of 50 or $100 \mu \mathrm{g}$. blood group substance.

\section{RESULTS}

That wide differences exist in the fucose content of the individual blood group $A$ and $O$ preparations may be seen from Tables I and II. The hog substances vary from 6 to about 13 per cent and the human preparations exhibit a somewhat similar variation; i.e., 9 to 16 per cent. The average methylpentose content of the human blood group substances (approximately 13 per cent) is higher than that of the hog substances (approximately 9 per cent). Table I also gives the amount of total nitrogen precipitated from $0.5 \mathrm{ml}$. of Type XIV antipneumococcal serum $\mathrm{H} 635$ by $500 \mu \mathrm{g}$. of the various hog blood group $\mathrm{A}$ and $\mathrm{O}$ substances; with few exceptions data were previously reported (5). Fig. 1 shows a plot of the amount of nitrogen precipitated by $500 \mu \mathrm{g}$. of hog substance from $0.5 \mathrm{ml}$. of Type XIV serum against the percentage of methylpentose. The numbers represent the number of the hog blood group preparation. It is evident that there is an inverse relationship between the methylpentose content of the various hog $\mathrm{A}$ and $\mathrm{O}$ substances and the cross-reactivity. A similar type of curve was obtained when the amount of nitrogen precipitated by $250 \mu \mathrm{g}$. of blood group substance was plotted against the fucose content of the hog $\mathrm{A}$ and $O$ substances. 
No such relationship was evident when the data (5) on the cross-reactivity of the human blood group substances were compared with their methylpentose contents (Table II).

TABLE II

Fucose Content of Human Blood Group $A, B$, and $O$ Substances

\begin{tabular}{|c|c|c|c|c|c|c|c|c|}
\hline $\begin{array}{l}\text { Blood group } \\
\text { A substance }\end{array}$ & 总 & 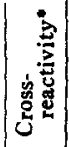 & $\begin{array}{l}\text { Blood group } \\
\text { B substance }\end{array}$ & 葶 & 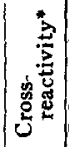 & $\begin{array}{l}\text { Blood group } \\
\text { O substance }\end{array}$ & 岁 & 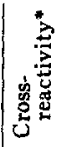 \\
\hline & $\begin{array}{l}\text { per } \\
\text { cent }\end{array}$ & $\mu g . N$ & & $\begin{array}{l}\text { per } \\
\text { cent }\end{array}$ & $\mu g . N$ & & $\begin{array}{c}\text { per } \\
\text { cent }\end{array}$ & ag. $N$ \\
\hline Saliva & & & Saliva & & & Saliva & & \\
\hline $\begin{array}{l}\text { W.H.1 } 10 \text { per cent } \\
\text { ppt. }\end{array}$ & 14.0 & 55 & $\begin{array}{l}\text { S.E. } 10 \text { per cent } \\
\text { ppt. }\end{array}$ & 11.6 & 65 & Bd. phenol-insol. & 8.8 & \\
\hline W.H.1 phenol-insol. & 13.9 & 81 & S.E. phenol-in- & 13.0 & 56 & Bd. digest of wa- & 12.4 & \\
\hline $\begin{array}{l}\text { W.H.2 } 10 \text { per cent } \\
\text { ppt. }\end{array}$ & 15.4 & 102 & sol. & & & $\begin{array}{l}\text { ter-insol., phen- } \\
\text { ol-insol. }\end{array}$ & & \\
\hline $\begin{array}{l}\text { W.H., digest of wa- } \\
\text { ter-insol. } 10 \text { per } \\
\text { cent ppt. }\end{array}$ & 12.9 & & & & & $\begin{array}{l}\text { Bd. } 10 \text { per cent } \\
\text { ppt. } \\
\text { Bd. not digested }\end{array}$ & $\begin{array}{c}8.4 \\
11.2\end{array} \mid$ & 42 \\
\hline $\begin{array}{l}\text { W.H.2 undigested } \\
\text { phenol-insol. }\end{array}$ & 12.3 & 58 & & & & $\begin{array}{l}\text { phenol-insol. } \\
\text { Bd. digest of wa- }\end{array}$ & 9.2 & \\
\hline $\begin{array}{l}\text { G.C. } 10 \text { per cent } \\
\text { ppt. }\end{array}$ & 16.0 & & & & & $\begin{array}{l}\text { ter-insol. } 10 \text { per } \\
\text { cent ppt. }\end{array}$ & & \\
\hline G.C. phenol-insol. & 13.0 & 60 & & & & F.P. 10 per cent & 14.6 & 105 \\
\hline B.K. phenol-insol. & 12.4 & 86 & & & & ppt. & & \\
\hline $\begin{array}{l}\text { B.K. } 10 \text { per cent } \\
\text { ppt. }\end{array}$ & 11.0 & 81 & & & & $\begin{array}{l}\text { F.P. digest of water } \\
\text { insol. phenol-in- }\end{array}$ & 18.4 & \\
\hline $\begin{array}{l}\text { A.K. } 10 \text { per cent } \\
\text { ppt. }\end{array}$ & 16.4 & & & & & $\begin{array}{l}\text { sol. } \\
\text { F.P. digest of wa- }\end{array}$ & 13.8 & \\
\hline $\begin{array}{l}\text { M.S. } 10 \text { per cent } \\
\text { ppt. }\end{array}$ & 11.4 & & & & & $\begin{array}{l}\text { ter-insol., } 10 \text { per } \\
\text { cent ppt. } \\
\text { F.P. not digested }\end{array}$ & $\mid 11.2$ & \\
\hline $\begin{array}{l}\text { Amniotic fluid I } \\
\text { phenol-insol. }\end{array}$ & 9.6 & 125 & & & & phenol-insol. & & \\
\hline $\begin{array}{l}\text { Amniotic fluid I } 10 \\
\text { per cent ppt. }\end{array}$ & 13.3 & & & & & Human stomach 5 & 12.6 & 72 \\
\hline Human stomach 1 & 9.0 & 65 & & & & & & \\
\hline Human stomach 2 & 11.0 & 62 & & & & & & \\
\hline Human stomach 3 & 16.0 & 29 & & & & & & \\
\hline Human stornach 4 & 11.5 & 50 & & & & & & \\
\hline
\end{tabular}

* $\mu \mathrm{g}$. $\mathrm{N}$ precipitated by $500 \mu \mathrm{g}$. of blood group substance from $0.5 \mathrm{ml}$. of Type XIV antipneumococcal horse serum H635.

DISCUSSION

The inverse relationship between cross-reactivity with Type XIV antiserum and fucose content provides further information about the structure of hog 
blood group $A$ and $O$ substances. It is in accord with the concept advanced in the preceding paper that fucose residues of the blood group substances project as end groups, from a basic chain of $N$-acetylglucosamine-galactose units and that these fucose residues reduce the cross-reactivity of the substances either by covering reactive groups on the main chain or by preventing antibody molecules from approaching sufficiently close to the main chain to react with free crossreactive sites. The present finding that the individual hog $\mathrm{A}$ and $\mathrm{O}$ substances may have different fucose contents (Table $I$ ) and that their capacity to cross-

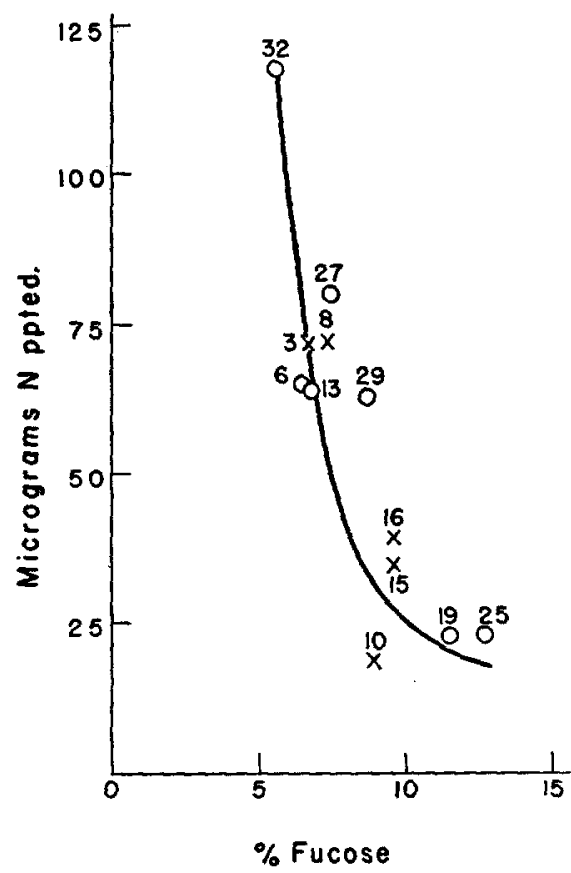

FIG. 1. Relation between fucose content and cross-reactivity of hog $A$ and $O$ substances with Type XIV antipneumococcal horse serum H635. $x=$ hog A substances; $O$ hog $O$ substances. Ordinate $=$ micrograms $N$ precipitated by $500 \mu \mathrm{g}$. blood group substance from 0.5 ml. antiserum.

react with Type XIV antibody varies inversely with their fucose content (Fig. 1) provides strong support for this concept and in addition accounts completely for the variation in cross-reactivity of hog blood group A preparations of identical blood group A activity (5). It would appear from the curve in Fig. 1 that the ratio of fucose residues to the total number of residues in the main chain reaches a limit, which, from the slope of the curve, is probably not much greater than about 15 per cent, and corresponds to about one fucose side chain to about every three or four hexose residues in the main chain.

Since the blood group A substances, which have been shown to be identical in blood group A activity, may vary widely in their fucose contents, it is evident 
that a considerable proportion of the fucose is not essential for blood group activity. For instance hog 16 with 9.6 per cent of fucose showed the same capacity to precipitate anti-A and the same purity based on glucosamine analyses of specific precipitates as did hog 3 with but 6.6 per cent fucose, hog 8 with 7.3 per cent, hog 5 with 8.3 per cent fucose, or hog 10 with 8.9 per cent fucose $(7,2)$. Furthermore, the relation between cross-reactivity and fucose content does not depend upon whether the individual blood group substance exhibits $\mathrm{A}$ activity or $\mathrm{O}$ activity or both, since all of the hog substances lie on the same curve (Fig. 1) indicating that blood group specificity is not determined by this variation in fucose content. Analyses of specific precipitates of A substance and anti-A (7) for their fucose content should provide further information on the relationship of the fucose to the blood group substances.

No correlation between cross-reactivity and fucose content was evident for the human blood group substances. This is not surprising since the substances appear to show a greater complexity than do the hog substances. The individual human blood group A substances showed greater variability than did the hog substances in their analytical properties and in their blood group activity. Furthermore, the substances from human saliva after peptic digestion, unlike the hog substances, occurred in two fractions, a phenol-insoluble and a phenolsoluble fraction from which the blood group substance could be precipitated by 10 per cent alcohol.

\section{SUMMARY}

It has been possible, by employing a new color reaction for methylpentoses, to determine the fucose content of individual hog and human blood group $\mathrm{A}, \mathrm{B}$, and $O$ substances. The data indicate an inverse correlation between fucose content of the hog $\mathrm{A}$ and $\mathrm{O}$ substances and ability to cross-react with Type XIV antipneumococcus serum. The human $A, B$, and $O$ substances display no correlation between their fucose content and ability to cross-react with Type XIV antipneumococcus serum.

\section{BIBLIOGRAPHY}

1. Bray, H. G., Henry, H., and Stacey, M., Biochem. J., 1946, 40, 124.

2. Bendich, A., Kabat, E. A., and Bezer, A. E., J. Am. Chem. Soc., 1947, 69, 2163.

3. Partridge, S. M., Biochem. J., 1948, 48, 251.

4. Kabat, E. A., Baer, H., Bezer, A. E., and Knaub, V., J. Exp. Med., 1948, 88, 43.

5. Kabat, E. A., Bendich, A., Bezer, A. E., and Knaub, V., J. Exp. Med., 1948, 87, 295.

6. Dische, Z., Fed. Proc. 1947, 6, 248 . Dische, Z., and Shettles, L. B., J. Biol. Chem., in press.

7. Bendich, A., Kabat, E. A., and Bezer, A. E., J. Exp. Med., 1946, 83, 485.

8. Kabat, E. A., Bendich, A., Bezer, A. E., and Beiser, S. M., J. Exp. Med., 1947, $85,685$. 